\title{
Всеволод Кузнецов
}

\section{ПРОСВЕЩЕНИЕ И ОНТОЛОГИЯ. ПРОСВЕЩЕНИЯ АВТОХТОННЫЕ: ЕВРОПА}

Данная статья открывает цикл работ, в котором предпринята попытка рассмотрения некоторых сущностных аспектов феномена Просвещения. Проведенные исследования должны, по мысли автора, стать шагом на пути к выработке болееменее четкого понимания сути и грании означенного феномена. Проблема заключается в том, что хотя о Просвещении написано много, четкость трактовок можно встретить преимущественно там, где речь идет о формационном подходе. Вот, к примеру: «Просвещение - раннебуржуазная, антифеодальная идеология, отвергающая феодально-крепостнический строй, как противоречащий разуму и природе человека» [Некрасова и др., 2008].

Но формационный подход не может объяснить существования типологически сходных с Просвещением феноменов в другие исторические эпохи, не связанные с формированием капиталистических отношений. Меж тем, представления, согласно которым Просвещение в жизни человечества «не раз» составляло «историческую эпоху духовного развития» [Просвещение, 2005], сегодня достаточно широко распространены, причем как на постсоветском пространстве, так и на Западе.

Однако здесь-то и начинаются настоящие сложности. Возьмем в качестве образца одну из расширительных трактовок интересующего нас явления: «На відміну від культурних змін, зумовлених зовнішніми чинниками (скажімо, війною), філософія більше переймається змінами, спричиненими процесом внутрішньої рефлексії культури, - процесом, який, охоплюючи суспільну (öffentlichen) свідомість цілої доби, і називається просвітництвом. Просвітництво в такому розумінні не обмежується визначенням певної історичної доби (скажімо, XVII та XVIII століть), а $\epsilon$ структурним моментом історичного розвитку, що, започаткувавшись грецькою софістикою, в перебігу європейської історії раз у раз повторюється» [Гьосле, 2003: c. 54]. Далее поясняется, что Просвещение есть «конститутивний момент різних циклів, з яких складається історія думки: грецька софістика, елліністично-римський скептицизм, середньовічний номіналізм, новоєвропейське просвітництво та різноманітні критичні теорії сучасного циклу - всі вони подібні в одному, а саме - у вираженні фази заперечення, в спрямуванні суб'єктивної рефлексії проти влади традиції, звичаїв, релігії, а також проти “тетичної” філософії, яка їх легітимує» [там же, с. 54-55].

\footnotetext{
(C) В. Кузнецов, 2013
} 
Автор цитированных строк приписывает Просвещению не только отрицание, критику и переоценку ценностей, но и стремление менять сами критерии оценивания [там же, с. 55]. «Оскільки ж без норм жити неможливо, просвітництво, спираючись на принцип суб'єктивної рефлексії, звертається до “обгрунтування”, запевняючи, що його норми є наслідком вільного від зовнішнього авторитету найавтентичнішого міркування, пов'язаного з його власною, цілком окремою, суб'єктивністю» [там же, с. 56]. Более того, «просвітництво в своїх догматичних формах висуває утопії та ідеали, які не мають нічого спільного не тільки $з$ фактичним виміром дійсності, а й з ії сутністю» [там же, с. 57]. В итоге закономерно следует вывод, согласно которому Просвещение «здатне радше на гостру критику, ніж на обгрунтування позитивних норм» [там же, с. 56]. Таким образом, здесь абсолютизируется одна из возможных функций Просвещения, общеобязательность которой нужно еще доказывать.

Просвещение может рассматриваться не только как постоянный фактор развития европейской цивилизации, но и как явление общечеловеческого масштаба. Так, П. С. Шкуринов пишет: «<.. > Явления просветительства знакомы всем социальным формациям и находят достаточно яркое выражение не только в секуляризованной форме, но и в религиозной, мифологической и смешанных формах. В общих чертах широкое и неформационное понимание просвещения позволяет с полным основанием считать просвещение древнейшим явлением. Оно представляет собой одну из важнейших черт духовности общества, его способности на определенном этапе подниматься над уровнем материальных потребностей, выступать генерализующей силой, объединяющей волю, мысль и нравственные убеждения людей. Человечеству известны просветительные эпохи древнекитайской, ассирийской, древнеяпонской, древнеиндийской, древнегреческой, древнеегипетской, древнеиудейской, древнеримской, древнеамериканской, арабской, христианской и других цивилизаций. Наиболее яркие периоды их истории знаменуются явным преобладанием идеальных, духовных ценностей, которые возбуждали нравственную энергию отдельного человека и народа в целом» [Шкуринов, 1992: с. 17].

Объявив Просвещение чем-то связанным с духовностью, исследователь пытается выявить его характерные особенности. Перво-наперво П. С. Шкуринов приписывает изучаемому феномену загадочную способность полно выражать дух времени, а затем добавляет сюда творческое отношение к наследию прошлого: «Поскольку просвещение, с одной стороны, обусловлено объективными процессами времени, а с другой выступает в качестве радикального требования разума, субъекта, постольку оно наиболее полно выражает дух времени. Характерно, что просветителям свойственны и критическое отношение к прошлому, и непременный интерес к истории, попытка удержать все ценное, что в ней накопилось. Такая ориентация просветительства обеспечила ему собственное долгожительство: человечество не может пренебрегать фактором, гарантирующим и преемственность, и мобильность» [там же, с. 17-18].

Понимая, вероятно, что подобные характеристики приложимы в принципе к чему угодно, П. С. Шкуринов стремится резко увеличить количество выявленных признаков Просвещения и делает это довольно бессистемно: «Необходимо также отметить, что просвещение предполагает новый, более высокий уровень концептуализации понятий. Повышение роли философии, науки, культуры в обществе, выработка ими новых парадигм развития, усиление связи теории с жизнью, расширение возможностей человека покорять в свою пользу стихии природы, укрепление нравственных, культурных, эстетических и педагогических средств, правовых 
взглядов и демократических, гуманистических представлений и норм жизни людей все это и немало другого тесно связано с понятием “духовность человека, общества”. Последнее (духовность) составляет комплекс форм, в том или ином объеме входящих в содержание понятия “просветительство" (“просвещение”) в широком его значении. Просвещение - явление человеческой самоорганизации, ее духовное начало и движущая сила» [там же, с. 18]. Результат налицо: перефразируя слова классика, можно сказать, что Просвещение выступает здесь воплощением всего общечеловеческого, доброго и круглого.

Справедливости ради следует отметить, что от расплывчатости несвободны и работы, в которых Просвещение анализируется в рамках формационного и близких к нему подходов. Возьмем для примера статью К. Л. Ерофеевой, посвященную просвещенческому идеалу. Согласно аннотации, в ней «рассматривается идейная парадигма эпохи Просвещения и проблема ее актуальности в современной постиндустриальной культуре» [Ерофеева, 2010: с. 90]. Однако как раз парадигмы как некой системы характеристик тут и нет. Разрозненные фрагменты ее хаотически разбросаны по всему тексту и с трудом складываются в единое целое. Приведу эти фрагменты в порядке обнаружения.

1) «Идеал Просвещения едва ли не так же высок, как идеал христианский: если христианская религия, как ни одна другая, апеллирует к самостоятельной, духовно зрелой личности, то идеология Просвещения - к личности еще более повзрослевшей, способной обходиться даже без религиозной веры» [там же, с. 90].

2) «Просвещение <..> провозгласило простые и очевидные истины: человек имеет право на свободу и счастье, знание дает ему новые возможности, в том числе по преобразованию самой социальной жизни...» [там же, с. 91].

3) «Поклонение человеческому разуму - одна из главных особенностей Просвещения. Это поклонение сопряжено с весьма противоречивым отношением к религии, к самой идее Бога. С одной стороны, сами просветители в большинстве своем не были атеистами, а выступали лишь против крайностей религиозного обскурантизма, с другой - Просвещение закономерно породило атеизм как самостоятельное течение мысли. Столь же закономерным стало обожествление самой науки» [там же, 91-92].

4) Просвещению свойствен антропоцентризм [там же, с. 93].

5) «<..> Идеология Просвещения отметает всяческий фатализм и предполагает для человека и общества только опору на собственные силы - силы воли и разума» [там же, с. 95].

6) «Социальный оптимизм - это тоже одна из важнейших установок Просвещения» [там же].

Часть из названных признаков - характеристики европейской культуры периода становления капитализма, в той или иной степени отраженные классическим европейским Просвещением. Часть нуждается в корректировке или вообще спорна. И лишь вскользь упомянут действительно сущностный момент: из всех социальных функций культуры «для парадигмы Просвещения безусловный приоритет оставался за воспитательной функцией» [там же, с. 90]. В целом же и тут мы имеем дело с представлениями о Просвещении как о воплощении всего доброго и круглого.

Такому этически-геометрическому восприятию я пытаюсь противопоставить подход, базирующийся на следующем тезисе: сущность Просвещения определяется его эдукационистской направленностью, а светлье идеаль, обозначающие ичель эдукачионного усилия вторичны и исторически изменчивы. 
Поэтому в данной работе Просвещение рассматривается как культурный феномен, возникающий в результате выхода эдукационной деятельности за рамки существующей в каждом обществе эдукационной сферы. Означенный выход осуществляется таким образом, что эдукационная деятельность перенацеливается на работу с Природой как обобщением вселенского целого (внешней природой) и внутренней природой вещей - прежде всего с естеством отдельного человека, различных человеческих общностей, а в предельных случаях также и космоса. Подобный подход неминуемо выводит эдукацию на онтологический уровень, превращает ее в способ манипуляции с бытием.

Иначе говоря, Просвещение есть совокупность способов и методов онтологизацчии эдукаџионной деятельности, а также набор культурных смыслов, служащих основанием для такой онтологизации и ее продуктом. Означенные способы, методы и смысльь возникают в условиях резкого повышения цивилизационной значимости эдукации. Следует, однако, заметить, что эдукационные манипуляции с бытием могут повлечь за собой как повышение, так и понижение онтологического статуса объекта эдукации. Они бывают нацелены на вхождение в бытие, закрепление в бытии и, говоря хайдеггеровским языком, на ничтожение, забвение бытия. Поэтому можно утверждать, что Просвещчение пытается формировать стратегии онтологизации и деонтологизации тьмы вещей.

Исходя из этих основных посылок, я попытаюсь поставить вопрос о специфике механизмов формирования и применения просвещенческих онтологизационных / деонтологизационных стратегий. В качестве конкретного материала меня будет интересовать в первую очередь русское Просвещение. Однако я осознаю, что для формулирования даже самых предварительных выводов анализа одной разновидности Просвещения может оказаться недостаточно. Поэтому для сопоставления будут использованы онтологические характеристики европейского и китайского Просвещения. Подобный подход представляется мне целесообразным, поскольку, с одной стороны, русское Просвещение генетически связано с европейским, но, с другой, русская культура по многим параметрам типологически сходна с китайской, а это заставляет предполагать и определенное сходство Просвещений. Кроме того, здесь открывается возможность для сопоставления Просвещений 1) автохтонных, 2) пересаженных на чужую почву, а также 3) развившихся из пришлых.

В первых четырех статьях данного цикла я как раз и буду сравнивать два автохтонных Просвещения с Просвещением, имплантированным в тело чуждой ему цивилизации. Здесь, однако, необходимо сделать одно существенное замечание. В свое время я назвал Россию рубежом, «на который европейское Просвещение сумело выдвинуться, все еще оставаясь самим собой» [Кузнецов, 2005a: с. 168]. В дальнейшем я изменил свою точку зрения и теперь полагаю, что таким рубежом Россия являлась лишь в XVIII - начале XIX в. Это период существования Просвещения, заимствованного из Европы, - Просвещения-в-России, как я его называю. Впрочем, даже для этого периода нельзя утверждать, будто европейское Просвещение на русской почве полностью осталось собой. С самого начала, т. е. с петровских времен, в нем происходили изменения, постепенное накопление которых уже в 30-х - 40-х гг. XIX в. привело к трансформации Просвещения-в-России в русское Просвещение.

Итак, перед нами европейское Просвещение в его истинном обличье, китайское Просвещение и европейское Просвещение на дальнем рубеже в процессе фатальной трансформации. Начнем с Европы. Именно ей и посвящена первая статья цикла. 
Выход эдукационной деятельности за рамки эдукационной сферы чаще всего происходит в ситуации нестабильности, нарушения устоявшегося порядка в обществе. Поэтому Просвещение в своем генезисе связано с кризисами. Часто - с цивилизационными. Кризис же имеет ту неприятную особенность, что, охватывая какуюлибо цивилизацию, покушается на ее базовые онтологизирующие структуры.

Для античности базовой онтологизирующей структурой является полис. Здесь уместно вспомнить, что бытие в античности неразрывно связано с благом [Гайденко, 1988: с. 293]. При этом само благо часто оказывается выше, первичнее и, так сказать, онтологичнее бытия. Поэтому там, где речь заходит о благе, там сознательно или неосознанно обращаются к онтологии. Полис же в античном понимании есть общность, обеспечивающая благую жизнь [Античная Греция, 1983: т. 1, с. 11-12; Платон, 1990-1994: т. 4, с. 78; Аристотель, 1976-1983: т. 4, с. 376, 378]. Полис подобен космосу и, как и космос, является живым и порождающим жизнь существом [Античная Греция, 1983: т. 1, с. 14]. Поэтому полис порождает человека, открывает ему его онтологическое место. Естественно, что полис и сам становится благом.

Но полис - структура неустойчивая. Он просто не может быть не подвержен многоразличным кризисам. И вот Пелопоннесская война (431 - 404 гг. до н. э.) открыла череду кризисов полиса [История древнего мира, 1982a: с. 233]. Полисная идеология была поколеблена деятельностью многих героев раннеклассической эпохи вроде Фукидида и Павсания [Фролов, 1984: с. 17]. А тут подоспело и античное Предпросвещение в лице софистов и Сократа. Софисты нанесли мощный удар по полису, настаивая на относительности устанавливаемых им норм [там же, с. 30-31]. Но полисом дело не ограничилось. Поскольку полис и космос взаимоподобны, атака на полис предполагала необходимость атаки на космос.

Тезисы Протагора о всеобеей изменчивости, о зависимом существовании и возникновении всех вещей [Чанышев, 1981: с. 206] фактически вели к виртуализации мира. Положение же о человеке как мере всех вещей означало попытку выдвижения человека на должность Верховного Онтологизатора, утверждающего права вещей на бытие, и создавало предпосылки для породнения бытия не с истиной, а с мнением. Софисты, таким образом, направляли усилия на деонтологизацию полиса и космоса.

Реонтологизирующую тенденцию античного Предпросвещения выражал Сократ, пытавшийся вернуть космосу благо, истину и бытие. Характерно, что в платоновском «Критоне» Сократ выступает с апологией полиса (знаменитые речи Законов и Государства). Человек изображен здесь как дитя полиса, получающее свое бытие от Законов [Платон, 1990-1994: т. 1, с. 106-107]. При этом Законы создают человека и как живое существо и как гражданина.

Отец античного Просвещения Платон продолжил развивать реонтологизирующую тенденцию Сократа. Философ учил о возможности приобщения к благу и бытию в триедином процессе познания-обучения-воспитания. При этом благо мыслилось Платоном как причина знания и истины, источник бытия и существования, основание единства и упорядоченности [Баумейстер, 2009: с. 221]. По мнению П. П. Гайденко, платоновское благо тождественно Единому [Гайденко, 1988: с. 294].

Что же касается космоса, то он, с одной стороны, как будто бы представлялся мыслителю онтологизированным, о чем свидетельствуют хотя бы определения из «Тимея» [Платон, 1990-1994: т. 3, с. 435-437, 500]. С другой стороны, миф о пещере возвращает нас к деонтологизированному, виртуализованному космосу. Мало того. 
Одной из основ космоса оказывается хора - неощутимое, иллюзорное пространство, постигаемое с помощью «незаконных умозаключений» [там же, с. 455]. Одним словом, хора - «почти что небытие» [Чанышев, 1981: с. 253]. И это «почти что небытие» в значительной мере деонтологизирует космос.

Но главной проблемой для Платона стала проблема онтологизации человека. Она решалась преимущественно просвещенческими средствами (через процесс познания-эдукации). Сам эдукационный процесс превратился у Платона в процесс трансляции бытия, передачи его из божественного мира в земной.

Решающую роль в означенном процессе играет, согласно Платону, Эрос, тождественный сократовскому даймониону и неведомому богу «Теэтета» [Прокопенко, 2012: c. 69]. Эрос-даймонион устанавливает связь между учениками и учителем, а также между учителем, учениками и богами, позволяя обучаемым обрести, кроме земного, еще и божественного наставника [там же, с. 68-69]. Но тот же Эрос в плане космическом выступает как осуществление всеединства, соединяя противоположности в мире земном, неразрывно связывая земное и горнее, сопрягая вечное и бессмертное бытие с изменчивым и смертным [Реале, 2005: с. XXXII]. Поэтому эротизированная эдукация оказывается вхождением во всеединство.

Кроме того, Эрос через порождение в красоте непрерывно продлевает смертное бытие, делая его бессмертным и таким способом приобщая к вечному и бессмертному Благу [там же, с. XXXV]. Рождение в красоте осуществляется не только в телесной, но и в духовной сфере. Под воздействием Эроса «душевнобеременные» воспитатели ищут в качестве объекта эдукации прекрасные души, соединяясь с ними, рождают прекрасные слова, побуждающие воспитуемых к совершенствованию [там же, с. XXXVI]. Влюбленные воспитатели формируют в объектах любви добродетели и одновременно совершенствуются сами [там же, с. XXXVII]. Воспитатели и воспитуемые совместно движутся к Благу. Так смертное и преходящее объединяется с вечным и бессмертным в эдукационном процессе.

Впрочем, у Платона присутствовало и понимание того, что процесс онтологизации должен быть для надежности подкреплен внепросвещенческими методами (через создание идеального государства, дарящего людям единство во благе [Платон, 1990-1994: т. 3, с. 189, 238-239]). Однако идеальное государство так и осталось мечтой. Поэтому реонтологизационные мероприятия Платона могли опираться лишь на силу Просвещения.

Деонтологизирующая тенденция античного Просвещения представлена стоиками. Эта школа вела подкоп под полисные ценности, подменяя полис космосом. Характеристики полиса переносились на космос. И если последний при этом сохранял свою онтологичность, то первый ее стремительно утрачивал. Стоики покусились и на деонтологизацию блага, отождествляя его с пользой [Диоген Лаэртский, 1979: с. 297]. Главным благом оказывалась у стоиков добродетель, которую они трактовали «как некоторый склад души, диспозицию < ..> посредством которой выбирается, что есть добро и что есть зло» [Титаренко, 2002: с. 114]. Таким образом, деонтологизация блага была связана с его психологизацией.

Стоики утверждали, что человеку свойственно стремиться к добродетели от природы (этого требует и вселенская природа и человеческое естество) [Гаджикурбанова, б. г.]. Критерием же того, что можно считать добродетельным, оказывался сверхчеловек - мудрец, природа которого тождественна вселенской природе. Собственно, добродетельными признавались любые действия мудреца, который 
получал право на нарушение всех общепринятых норм [Гаджикурбанова, 2004]. Таким образом, понятия добродетели фактически релятивизировалось.

Впрочем, стоическая деонтологизация отнюдь не была абсолютной и тотальной. Школа пыталась предложить и свой вариант реонтологизации человека. Он заключался в восхождении от животной природы через социальную к моральной [Гаджикурбанова, б. г.]. На высшей стадии развития достигалось тождество естества подвизающегося с вселенской природой. Подвизающийся приобщался к космическому бытию и достигал онтологического места сверхчеловека-мудреца. Утверждение адепта в бытии достигалось чисто просвещенческими методами.

Однако эту реонтологизационную попытку нельзя счесть вполне успешной. Стоикам и здесь мешал космоцентризм. Как верно заметила И. Н. Титаренко, в стоицизме «человек - это не только самодетерминирующаяся индивидуальность, но и частица всеобщего миропорядка, сколок Вселенной, в котором, как в зеркале, отражаются ее законы. <..> Стоический мир - живая и одухотворенная огненная субстанция, и все представляется как ее модификации. Субъект со всеми его познавательными способностями, со своей природой и своей внутренней логикой тоже истечение объективно и вечно существующего божественного огня, или, используя более поздний термин, - модус субстанции, главной функцией которого является творческая способность, или возможность свободного самоопределения. Стоический мудрец, не имея целью лишь формальное подражание природе, в идеальном случае осуществляет в своем внутреннем субъективном существовании объективный природный закон. Он может быть рассмотрен только как реализация космической закономерности <...>» [Титаренко, 2002: с. 212].

Бытие модуса не есть его собственное бытие, но бытие субстанции. Онтологическое место сверхчеловека оборачивается не-местом. Иначе говоря, налицо парадокс. Стремящийся к добродетели возрастает в бытии, но достигший ее безбытийствен. Или, точнее, поднявшись ко всебытию, он безвозвратно утрачивает самобытие.

Специфика стоического способа онтологизации эдукационной деятельности хорошо прослеживается на примере учения Сенеки. Философ, как и положено стоику, отождествляет благо и добродетель. Так, о правильно ориентированном разуме сказано, что он есть и добродетель и благо: «Наес vocatur virtus, hoc est honestum et unicum hominis bonum» [Seneca, MCMXX: LXXVI, 16, p. 154, 156]. К слову, триада «разум - добродетель - благо» вообще представляет у Сенеки устойчивую целостность [ibid., LXVI, 39-42; LXXVI, 10-11, p. 24, 26, 152]. Кроме того, мыслитель подчеркивает исключительную полезность блага: «Non est id bonum, quod plus prodest, sed quod tantum prodest» [ibid, LXXXVII, 36-37, p. 344].

Благо-добродетель предельно психологизировано: «<... Есть одно благо - добродетель, и помимо нее благ нет; добродетель заключена в лучшей, то есть разумной, части нашего существа. Что же такое эта добродетель? Истинное и непоколебимое суждение; от него душа получает все побуждения, через него становятся ясны все те видимости, от которых побуждения исходят» [Сенека, 1977: LXXI, 32, с. 133].

Благо-добродетель обретается в эдукационном процессе. Добродетели учатся, и ее нет без образования [Seneca, MCMXX: XC, 46, p. 428, 430; Seneca, MCMXXV: CXXIII, 16, p. 434]. Движущей силой эдукации является стремление к добродетели (вновь психологизаторский момент) [Seneca, MCMXX: LXXI, 36, p. 94; LXXX, 4, p. 214]. Процесс обучения-воспитания выступает как процесс самоонтологизации. В нем обретается благо как онтологическое основание человеческой жизни. Благо это 
пребывает и обнаруживается внутри подвизающегося: «Summum bonum extrinsecus instrumenta non quaerit. Domi colitur, ex se totum est. $\langle\ldots>$ Omne intra se bonum terminabit <...>» [Seneca, MCMLXXIX: IX, 15, 18, p. 50, 52].

Самоонтологизация есть также самоподчинение и самообустройство. «Сенека сравнивает мудреца с Александром Македонским, ибо мудрец “завоевывает себя", подобно тому как полководец “завоевывал мир”. <..> Вместо завоевания мира самозавоевание, вместо построения империи - строительство собственной жизни, регулируемой разумом и управляемой причиной. $<\ldots>$ Качественная характеристика стоического мудреца, сближающая его с богом, - творение; только творение первого направлено внутрь, на себя, тогда как творение второго - вовне, на мир» [Титаренко, 2002: c. 125].

Завершает самоонтологизацию обретение самотождественности: «Но чтобы добродетель была совершенной, нужно еще вот что: пусть будет твоя жизнь равна себе, пусть ничто в ней не противоречит одно другому <..> Таково высшее благо» [Сенека, 1977: XXII, 8, с. 59].

Однако и сенековского мудреца ждет вхождение во всеединство. Вселенная открывается ему как сверхтело, частью которого он является: «Все, что ты видишь, в чем заключено и божественное и человеческое, - едино: мы - только члены огромного тела» [Сенека, 1977: XCV, 52, с. 238].

Но Сенека намечает еще один путь к онтологизации воспитуемого. Он заявляет Луцилию: «Adsero te mihi; meum opus es» [Seneca, MCMLXXIX: XXXIV, 2, p. 240]. В английском переводе: «I claim you for myself; you are my handiwork» [ibid, p. 241]. B русском: «Я притязаю на тебя: ты - мое создание» [Сенека, 1977: XXXIV, 2, с. 62]. Здесь мы видим тенденцию к приданию наставнику онтологизационных и демиургических функций. Впрочем, эта тема не развита должным образом.

Чтобы оценить по достоинству стоическое понимание эдукации следует отметить, что для любого полноценного Просвещения характерен акцент на человеческом эдукационном усилии. Такое положение вещей не меняется даже тогда, когда в том или ином учении присутствует Бог в роли Воспитателя. У стоиков перенос центра тяжести на человека доведен до логического завершения. Онтологизация эдукационной сферы осуществляется через прорыв человека к основаниям собственного бытия и обретение самотождественности. Деонтологизация завершает эдукационный процесс вхождением мудреца во всеединство.

Онтологизирующая и деонтологизирующая тенденции античного Просвещения долгое время пребывали в неустойчивом равновесии. Причем на ситуацию оказывали влияние и внепросвещенческие факторы. Так, полной деонтологизации мира препятствовала архетипическая для античной культуры концепция благого и прекрасного божественного космоса. Однако и эта концепция подверглась в конечном счете пересмотру. И итогом античного Просвещения стал гностицизм с его акосмизмом. Что же касается деонтологизации полиса, то она происходила быстрее по причине перманентного кризиса полисных структур. У тех же стоиков даже после римского обновления полисных ценностей уверенно восторжествовал космополитизм.

В средние века наступил перерыв в развитии европейского Просвещения. Но происходившие в поздней античности (при закладке фундамента средневековой культуры) и в самом средневековье мировоззренческие изменения оказали огромное воздействие на нововременное просвещенчество. 
Прежде всего, в средние века произошла демифологизация космоса. Космос лишался божественности, души и воли [Кураев, 1995: с. 326, 332]. Эта демифологизация являлась надежной предпосылкой радикальной деонтологизации мира. Деонтологизационная тенденция отчетливо проявилась уже у Оккама [там же, с. 332]. Впрочем, в рамках собственно средневекового мировоззрения (а тот же Оккам работает на его разрушение) подобная предпосылка еще не могла реализоваться полностью, ибо господствовало убеждение, что Бог надежно удерживает мир в бытии. Но некие деонтологизационные интенции подспудно ощущались всегда.

На закате средневековья разразился духовный кризис, подрывавший главную онтологизирующую структуру европейского общества того времени - церковь. Кризис начался с Авиньонского пленения пап и Великого раскола и существенно подорвал церковный авторитет. Помимо всего прочего, под сомнение была поставлена правомерность вынесения церковью суждений о бытии.

Однако если речь идет о взглядах на мир в целом, то здесь кризис сперва породил реонтологизационную тенденцию, поскольку Возрождение попыталось воскресить античную мифологему живого и божественного космоса. Но уже Реформация обозначила новый поворот (и поворот весьма решительный) к деонтологизации мира. Важной вехой на этом пути стал отказ от представлений об иерархичности мироустройства [там же, с. 334]. Результатом стало отрицание сущностного характера мироздания, лишение мира сущностных оснований [Философия эпохи ранних буржуазных революций, 1983: с. 73]. Естественно, таким образом воспринимаемый мир терпел фатальный ущерб в бытии.

Во 2-й пол. XVI - XVII веке кризис европейской цивилизации стал всеобъемлющим. Если ранее его развертывание обуславливалось в первую очередь взаимодействием духовной и социальной составляющей, то теперь к делу подключилась и экономика. П. Шоню указывает на проявившуюся после 1550 г. задержку экономического роста [Шоню, 2005: с. 12]. Упадок продолжался между 1600 и 1650 гг. [там же, с. 11]. Не улучшилась ситуация и в дальнейшем. Долговременный экономический подъем начался лишь в 1730 - 1775 гг. [там же, с. 396].

Этот тотальный упадок совпал с научной революцией, возводившей деонтологизационные процессы на качественно новый уровень. Причем речь не идет о простом совпадении во времени. Кризис онтологически обессиливал окружающую человека реальность и провоцировал патологические сдвиги мировосприятия. Изменения, произошедшие в ходе научной революции, М. Хайдеггер назвал превращением мира в картину.

Здесь важны два момента. Во-первых, Хайдеггер понимает мир как плерому сущего и подчеркивает, что сюда включается и основа мира в любом ее понимании. Во-вторых, мыслитель указывает на окончательное утверждение человека в роли Верховного Онтологизатора, поскольку теперь человек делает сущее сущим, представляя его, устанавливая в качестве предстоящей ему картины. А бытие оказывается тождественным представленности мира [Хайдеггер, 1993: с. 49].

В таких условиях и проявило себя нововременное Просвещение. Поскольку последнее пыталось опираться на деонтологизирующую мир науку (насколько удачно - отдельный разговор), постольку и само выступало в качестве деонтологизирующего начала. Впрочем, не все было так однозначно.

Возьмем, к примеру, родоначальника классического европейского Просвещения Френсиса Бэкона. О. Гомилко указывает, что этот философ осуществляет три 
редукции: «<..> редукцію світу до натурального порядку речей <..> редукцію людини до еgo (самосвідомого суб'єкта) <.. > редукцію внутрішнього світу людини (iі душі та духу) до розуму та свідомости» [Гомілко, с. 63]. Все это - деонтологизационные операции, осуществляемые в рамках программы превращения мира в картину. Особенно важна здесь первая редукция, ибо с ее помощью виртуализуется мир в целом [Кузнецов, 2006: с. 107]. Во втором случае «сутність людини редукується до еgо як носія когнітивних здатностей» [Гомілко, с. 63]. В третьем - «самозасвідчення людини обмежується сферою розуму та свідомости як ії (людини) сутнісних ознак» [там же]. Фактически тут идет процесс виртуализации человека, сведения его к некоему набору признаков. Важным моментом является также то, что во всех трех случаях деонтологизация выступает как десоматизация.

Однако деонтологизаторские и десоматизаторские поползновения перебиваются у Бэкона ресоматизаторскими и реонтологизаторскими устремлениями, которые выражены в идее рукотворного апокатастасиса [Кузнецов, 2006: с. 105-108]. Последний предполагает восстановление - реставрацию и ремонт, восстановление во всех правах - тленных вещей («restitutio et instauratio rerum corruptibilium»), а также стабилизацию тел в их «естественном» состоянии («corporum in statu suo conservatio») [Bacon: v. 13, p. 13].

Еще сильнее реонтологизационная тенденция выражена в эдукационистском проекте Бэкона. Последний ориентирован в первую очередь на воспитание разума. Философ заявляет: «Ни голая рука, ни предоставленный самому себе разум не имеют большой силы. Дело совершается орудиями и вспоможениями, которые нужны разуму не меньше, чем руке. И как орудия руки дают или направляют движение, так и умственные орудия дают разуму указания или предостерегают его» [Бэкон, 1977-1978: т. 2, с. 12]. Главным орудием является в данном случае истинно верный метод. Дрессура разума имеет целью подчинение его этому методу.

Онтологический статус разума определяется тем, что он есть «как бы божественный огонь» («Itaque naturae facienda est prorsus solutio et separatio, non per ignem certe, sed per mentem, tanquam ignem divinum») [Bacon: v. 1, p. 384]. Бог создал свет разума после «естественного» света. Он возжег свет в хаосе материи, а затем в человеке и, постоянно освещая творение сиянием Своего Духа, продолжает возжигать свет в избранных: «The first creature of God, in the works of the days, was the light of the sense; the last was the light of reason; and his Sabbath work ever since, is the illumination of his Spirit. First he breathed light upon the face of the matter or chaos; then he breathed light into the face of man; and still he breatheth and inspireth light into the face of his chosen» [ibid., v. 12, p. 82].

Казалось бы, чего же еще? Но Бэкон жаждет опровержения естественного разума, оставленного без надлежащего руководства («redargutione nimirum Humanae Rationis Nativae et sibi permissae») [ibid., v. 1, p. 320]. Естественный разум есть разум первообразный, соответствующий собственным онтологическим основаниям, что вытекает из смысла самого слова nativus. Однако философ не желает с этим соглашаться. И пускается в рассуждения о различиях между идолами человеческого ума и идеями Божественного разума, запечатленными в творении: «Non leve quiddam interest inter humanae mentis idola et divinae mentis ideas; hoc est, inter placita quaedam inania et veras signaturas atque impressiones factas in creaturis, prout inveniuntur» [ibid., p. 246].

Получается, что разум, соответствующий своему онтологическому статусу, - это разум, способный отражать Божественные идеи, адекватно постигая творение. 
Естественный разум таков лишь в потенции, ибо подвержен помрачению идолами. И напротив, обработанный и очищенный разум вполне соответствует своему статусу, предназначению и происхождению.

Кроме того, разум, лишенный должного руководства, не способен проникнуть во мрак вещей: «<..> Cum intellectus, nisi regatur et juvetur, res inasqualis sit, et omnino inliabilis ad superandam rerum obscuritatem» [ibid., v. 1, p. 245]. Но почему речь здесь идет о мраке? Ведь природа светоносна [ibid., v. 12, p. 444]. Конечно, в первую очередь, это - тьма неизведанного, мгла незнания. Но не только. В результате грехопадения Адама мир поражен грехом и порчей [ibid., p. 443-444]. Поэтому мрак вещей оказывается также тьмой греха. И если вспомнить, что осуществление апокатастасиса есть дело естественной философии, то задачей разума вполне может стать рассеивание этой самой тьмы. Особенно при наличии истинной связи между разумом и вещами, о восстановлении которой печется Бэкон [ibid., v. 1, p. 195].

И еще один нюанс. Слово praevaricatio - проступок, грех, преступление - означает также двуличие, двурушничество, тайное содействие противнику. Здесь тьма неведения и тьма греха смыкаются. Неведомое оказывается чем-то или даже кем-то, чьего истинного облика мы не знаем, скрытым злом, выдающим себя за нечто иное. И только свет разума может высветлить подлинную сущность всех тайных сторонников врага...

Итак, правильно воспитанный разум реонтологизирован и способен осуществлять реонтологизацию.

Теперь - о субъекте эдукационного процесса, об онтологизаторе. В этой роли Бэкон видит самого себя: «<..> Мы решили испытать, не можем ли мы положить более прочное основание действенному могуществу и величию человеческому и расширить его границы» [Бэкон, 1977-1978: т. 2, с. 67]. Философ не создает какуюто теорию или школу, но осуществляет эдукационную работу над умами читателей своих произведений: «<..> Теперь, очистив, пригладив и выровняв площадь ума, остается еще утвердить ум в хорошем положении и как бы в благоприятном аспекте для того, что мы ему предложим» [там же]. Однако онтологизатор и сам обязан иметь твердые бытийные опоры. И здесь Бэкон не предлагает новшеств. Основой самоонтологизации является для него причастность к истине-благу: «<..> у нас есть, как мы полагаем, более правильные, более истинные и более плодотворные суждения, чем те, которыми люди пользуются до сих пор <...>» [там же].

Иную картину мы наблюдаем у де Сада, чье творчество - одна из вершин классического Просвещения. Персонажи произведений Сада делятся на людей, сверхчеловеков и недочеловеков. Играя в десоматизацию-ресоматизацию, маркиз проводит со всеми этими типами существ ритуалы перемены онтологического места-статуса [Кузнецов, 2003-2004]. В результате все тела-места утрачивают четкость границ и статусов, преобразуются в интенсивности, поглощаемые затем Мировым Телом (Матерью-Природой) [там же, с. 92-95]. Мировому Телу противопоставляется мир чистой энергии. Плерома энергий является онтологическим основанием Мирового Тела. Однако их онтологическая связь является извращенной. Поэтому Сад взыскует разрушения, деонтологизации Природы [Кузнецов, 2004: с. 59, 61]. Таким образом, в садической философии деонтологизационная тенденция явно преобладает. Симптоматично, что Сад при этом продолжает традиции Декарта, Спинозы и Ньютона [Кузнецов, 2004: с. 58-59]. Иначе говоря, садовская мифология маскирует все ту же рожденную в браке науки и философии картину мира. Что же касается эдукацион- 
ных практик, то у Сада они оказываются все той же десоматизационно-ресоматизационой игрой.

Классическое Просвещение погибло в огне цивилизационного кризиса, вызванного Великой французской революцией. А измененная этим кризисом Европа создала постклассическое Просвещение.

Одним из родоначальников просвещенческой постклассики является Карл Маркс. У раннего Маркса место трансцендентного начала, онтологизирующего мир, занимает жизнь [Нерушева, б. г.: с. 202]. Для человека же источником бытия, онтологическим основанием является род, родовая жизнь. Маркс утверждает: «Der Mensch ist ein Gattungswesen <...> [Marx, 1968: S. 515], что переводится как «человек есть родовое существо» («Человек есть существо родовое <...>» [Маркс, Энгельс, б. г.: т. 42, с. 92]). Но Wesen означает также бытие, существование, поэтому справедливым будет и перевод «человек есть родовое бытие».

Определяя онтологический статус человека, Маркс весьма специфическим образом воскрешает мифологему мирового тела как тела первочеловека. Вхождение человека во всеединство и обретение им космического статуса понимается философом как обретение универсальности через снятие границ между телом мира и человеческим телом, как превращение природы в человеческое (всечеловеческое) тело: «Die Universalität des Menschen erscheint praktisch eben in der Universalität, die die ganze Natur zu seinem unorganischen Körper macht, sowohl insofern sie 1. ein unmittelbares Lebensmittel, als inwiefern sie [2.] die Materie, der Gegenstand und das Werkzeug seiner Lebenstätigkeit ist» [Marx, 1968: S. 515-516].

Но такая постановка вопроса означает тотальную деонтологизацию природы. Маркс пытается решить возникшую проблему через провозглашение человека природным существом. Тогда связь природы и человека становится связью природы с самой собой: «Daß das physische und geistige Leben des Menschen mit der Natur zusammenhängt, hat keinen andren Sinn, als daß die Natur mit sich selbst zusammenhängt, denn der Mensch ist ein Teil der Natur» [ibid., S. 516]. И все было б хорошо, если б не сущность человека, которая есть «совокупность всех общественных отношений» [Маркс, Энгельс, б. г.: т. 3, с. 3]. Маркс не только утверждает это, но еще и критикует Фейербаха за понимание человеческой сущности как чего-то природного [там же]. Словом, исправить положение не удается.

К тому же у самого Маркса степень причастности человека бытию определяется его местом в системе общественного производства. При этом мыслителя интересует человек с разрушенной природой, человек максимально отчужденный от жизни, а следовательно, максимально деонтологизированный. Таким человеком является пролетарий [Нерушева, б. г.: с. 200]. Отчужденный труд через отчуждение природы как источника жизненных средств («Das Gattungsleben, sowohl beim Menschen als beim Tier, besteht physisch einmal darin, daß der Mensch (wie das Tier) von der unorganischen Natur lebt <..>» [Marx, 1968: S. 515]) и деятельностной функции как способа реализации родовой жизни («Das produktive Leben ist aber das Gattungsleben. Es ist das Leben erzeugende Leben» [ibid., S. 516]) отрывает человека от основ его бытия и нарушает онтологическую иерархию, превращая родовую жизнь в средство поддержания индивидуальной жизни: «Indem die entfremdete Arbeit dem Menschen 1. die Natur entfremdet, 2. sich selbst, seine eigne tätige Funktion, seine Lebenstätigkeit, so entfremdet sie dem Menschen die Gattung; sie macht ihm das Gattungsleben zum Mittel 
des individuellen Lebens. Erstens entfremdet sie das Gattungsleben und das individuelle Leben, und zweitens macht sie das letztere in seiner Abstraktion zum Zweck des ersten, ebenfalls in seiner abstrakten und entfremdeten Form» [ibid.].

В дальнейшем, однако, выясняется, что именно человек с разрушенной природой способен возвратиться к глубинным основам жизни, поскольку разрушение природы очистило его от всего затемняющего эту суть [Нерушева, б. г.: с. 202]. Таким образом, путь к реонтологизации лежит через максимальную деонтологизацию.

Тут следует обратить внимание на один важный момент. Л. Г. Нерушева совершенно справедливо указывает, что Маркс в своих ранних работах богословствует [там же, с. 194]. При этом исследовательница связывает квазитеологические конструкции основателя марксизма с ветхозаветным богословием [там же, с. 194-197, 202]. Я же полагаю, что у рассматриваемой марксовой конструкции, как минимум, два основания. Первое - действительно ветхозаветное. Второе - просвещенческое. Маркс в лучших просвещенческих традициях конструирует здесь идеальный (по просвещенческим меркам) объект эдукации, полностью лишенный природы и потому пригодный для любых эдукационных операций. Дело в том, что онтологизирующая составляющая европейского классического и постклассического Просвещения в идеале ориентирована на наделение бытием через наделение природой. По существу речь идет о сотворении бытия из меона. Но и меон тоже нужно создать. Поэтому акту наделения бытием предшествует деонтологизирующее, меонизирующее сотворение объектов без естества.

Реонтологизационный проект Маркса опирается на поддержку внепросвещенческих факторов и требует для своей реализации общественного переустройства. Дальнейшее развитие марксовой теории приводит к неуклонному возрастанию роли этих самых внепросвещенческих факторов и ставит означенную теорию на грань выхода за рамки Просвещения. Я полагаю, что роковой рубеж Маркс все же не переступает. Его философия в целом остается просвещенческой. Тем не менее отецоснователь задает возможность для развития своего детища как по просвещенческому, так и по непросвещенческому пути.

Здесь необходимо обратить внимание на следующий момент. По Марксу, конечная реонтологизация пролетариата должна осуществиться через социальную революцию. Но для подготовки рабочего класса к революционным действиям необходим эдукационный проект. Цель его - оформление исходного меона (превращение пролетариата в класс) и формирование предпосылок для перехода от небытия к бытию (порождение коммунистического сознания).

И тут мы видим две разные стратегии реализации данного проекта. Первая предполагает, что эдукационный процесс осуществляется в значительной мере стихийно: первоначально - самим развитием производительных сил, а затем - революционным движением масс. В результате «<..> возникает класс, который вынужден нести на себе все тяготы общества, не пользуясь его благами, который, будучи вытеснен из общества, неизбежно становится в самое решительное противоречие ко всем остальным классам; этот класс составляет большинство всех членов общества, и от него исходит сознание необходимости коренной революции, коммунистическое сознание, которое может, конечно, - благодаря пониманию положения этого класса, - образоваться и среди других классов <..> как для массового порождения этого коммунистического сознания, так и для достижения самой цели необходимо массовое изменение людей, которое возможно только в практическом движении, в 
революичии <...> [Маркс, Энгельс, б. г.: т. 3, с. 69-70]. Эта стратегия кажется непросвещенческой, ибо она сводит к минимуму роль сознательного эдукационного усилия людей.

Однако в «Тезисах о Фейербахе» Маркс проговаривает кое-что позволяющее взглянуть на данную стратегию несколько иначе: «Материалистическое учение о том, что люди суть продукты обстоятельств и воспитания, что, следовательно, изменившиеся люди суть продукты иных обстоятельств и изменённого воспитания, - это учение забывает, что обстоятельства изменяются именно людьми и что воспитатель сам должен быть воспитан. Оно неизбежно поэтому приходит к тому, что делит общество на две части, одна из которых возвышается над обществом (например, у Роберта Оуэна). Совпадение изменения обстоятельств и человеческой деятельности может рассматриваться и быть рационально понято только как революционная практика» [там же, с. 2].

На первый взгляд непросвещенческий характер разбираемой стратегии высвечивается «Тезисами» еще яснее. Ведь Маркс выступает здесь против устойчивого деления участников эдукационного процесса на воспитателей и воспитуемых. Но не стоит спешить с выводами. С одной стороны, такое деление - характерный признак Просвещения, с другой, сами просвещенцы достаточно часто против него бунтуют. Поэтому тут всегда важно понять, с какой целью поднимается бунт.

Маркс хочет сказать, что люди, вовлеченные в революционную борьбу, меняют и обстоятельства и самих себя. Они перевоспитывают себя. Иначе говоря, упор делается на самовоспитание. Таким образом, данная стратегия, в зависимости от расстановки основных акцентов, может приобретать и просвещенческую и непросвещенческую окраску. Ставим ударение на проблеме самоформирования борцов за дело рабочего класса и получаем вариант вполне приемлемый с точки зрения любого Просвещения. Упираем на роль объективных исторических законов и стихийности - и легко можем с просвещенчеством распрощаться.

Вторая стратегия требует наличия специальных воспитателей пролетариата коммунистов: «Ближайшая цель коммунистов та же, что и всех остальных пролетарских партий: формирование пролетариата в класс <...> [там же, т. 4, с. 437]. Эта стратегия - уже безусловно просвещенческая.

В числе наследников Маркса оказались как деятели, ориентированные на реализацию первой стратегии, так и те, кто связывал свои упования со второй. К последним принадлежал Ленин. Но о Владимире Ильиче речь еще впереди...

Основная направленность марксова учения была реонтологизацонной. Однако в нем наличествовал и деонтологизационный потенциал. Для разъяснения сути деонтологизационных интенций философии Маркса я позволю себе обратиться к рассуждениям А. Паныча. В своей статье «Філософія вчинку Бахтіна в контексті антиметафізичних проектів пізньомодерної європейської філософії» исследователь вводит понятие антиметафизического проекта. Термин «метафизика» А. Паныч считает синонимом «первой философии» в ее аристотелевском понимании [Панич, 2012: с. 6]. Предметом метафизики является «сущее как таковое, а также то, что ему присуще само по себе» [Аристотель, 1976-1983: т. 1, с. 119], а метод, которым она пользуется, предполагает обращение к своему предмету напрямую, без посредничества иных наук [Панич, 2012: c. 6]. Соответственно, антиметафизические проекты могут отрицать 1) сам предмет первой философии или возможность его познания, а также 2) метод, настаивая на необходимости посредников и посредничества [там же]. 
Маркс, согласно А. Панычу, начинает с построения своей собственной версии первой философии, т. е. с осуществления метафизического проекта. Затем, утвердив понимание производства как родовой жизни, мыслитель переходит к углубленному рассмотрению этой основы основ. И здесь он обнаруживает невозможность обойтись без посредников. Принимая посредничество политэкономии, Маркс трансформирует метафизический проект в антиметафизический [там же, с. 9-10].

Но отказ от непосредственного созерцания «сущего как сущего» есть путь к забвению онтологии. Если же мыслитель еще и избирает в качестве посредника науку, он автоматически подключается к деонтологизационной работе последней.

Еще хуже обстоит дело с Энгельсом [там же, с. 8-9]. Последний в своих работах «Анти-Дюринг» и «Людвиг Фейербах и конец немецкой классической философии» рисует перспективу постепенного поглощения философии наукой [Маркс, Энгельс, б. г.: т. 20, с. 142; т. 21, с. 316]. А при таком подходе никакие реонтологизаторские поползновения не в силах противостоять деонтологизирущему напору научного мировосприятия.

Основателем еще одного из главных течений европейского постклассического Просвещения стал Фрейд. Для его учения характерна онтологизация внутренней жизни человека [Лейбин, 1990: с. 102-103, 106-107]. Онтологическим основанием человеческой психики Фрейд признал бессознательное. Сознание же оказывалось вторичным, подчиненным началом [там же, с. 106, 109-111]. Однако в качестве цели психоаналитической работы (т. е. своего эдукационного проекта) Фрейд видел подчинение бессознательного сознанию, постановку Я на место Оно [там же, с. 112113]. Такая атака на онтологическое основание психического мира человека не могла означать ничего иного, кроме попытки деонтологизации последнего. Противоположная тенденция проявилась у многих последователей Фрейда в виде безудержной иррационализации человека [там же, с. 113]. Однако рационалистическидеонтологизационные устремления постоянно брали верх в психоанализе, поскольку Фрейд задал своему детищу ориентацию на науку [там же, с. 100].

Итак, в европейском постклассическом Просвещении деонтологизационные тенденции постепенно усиливаются. Еще хуже обстоит дело в Просвещении неклассическом (уже не европейском только, но западном). Деонтологизация осуществляется теперь за счет подмены природного начала различными искусственными конструктами. Как это происходит, я попытался показать в одной из своих работ на примере гендерной теории [Кузнецов, 2005: с. 119-123]. Как следствие любой эдукационный проект реализуется через манипуляции с неистинным бытием и дает на выходе еще одну разновидность все того же лжебытия. Данные процессы совпадают с торжеством хайдеггеровского забвения бытия в европейской (и всей западной) культуре.

Таким образом, можно сказать, что первоначально европейское Просвещение рождается из столкновения деонтологизационных и реонтологизационных тенденций (противостояние софистов и Сократа) в античной культуре, порожденных кризисом базовой онтологизирующей структуры античности - полиса. Далее борьба указанных тенденций продолжается в самом античном Просвещении и завершается в период гибели последнего с явным перевесом деонтологизирующего начала.

Впрочем, деонтологизационная тенденция в античной культуре не может прийти к своему логическому завершению, к тотальному бегству от бытия. Напротив, античная деонтологизация в конечном счете влечет за собой трансцендирование 
бытия и попытку человека стать лицом к лицу с ним, исключив посредничество космического целого (гностицизм). Той же природы и стремление средневекового человека преодолеть себя и мир ради непосредственного предстояния Богу-Бытию.

Второе рождение европейского Просвещения связано с глобальным цивилизационным кризисом, разразившимся на переходе от средневековья к Новому времени. Означенный кризис породил мощный деонтологизационный импульс, инициировавший процесс превращения мира в картину. Классическое, а затем и постклассическое Просвещение не очень уверенно пыталось противостоять волне деонтологизации, но в нем самом деонтологизационная тенденция одерживала победу за победой, пока, наконец, постклассика окончательно не превратила Просвещение в деонтологизационный инструмент.

Состоявшееся в Новое время превращение мира в картину отличается от античных деонтологизационных поползновений тем, что приводит к распаду духовных структур, обеспечивающих восприятие бытия, и потому толкает человека к полному забвению последнего. Нововременная наука лишает человека глаз, которыми можно узреть «стольность» и «чашность». Причем первоначально против человека используется именно его способность к онтологическому видению. А. Кураев совершенно справедливо указывает на то, что современное научное мышление не могло бы сформироваться без опоры на убежденность в существовании мира интеллигибельных сущностей [Кураев, 1995: с. 322-324]. Но требуется еще и радикальное низведение означенных сущностей в видимый мир [там же, с. 328]. А как только это низведение осуществлено, в дальнейшем уже легко подменять онтологические сущности созданными учеными теоретическими конструктами (их-то и называют законами природы, общества и истории), что в новой науке и происходит. Онтологическое видение вытесняется научным конструированием.

В целом Европа демонстрирует нам судьбу Просвещения в онтологически нестабильной цивилизации. Совершенно противоположный пример дает Китай. Здесь Просвещение развивается в рамках цивилизации онтологически стабильной. Китаю и будет посвящена следующая статья.

\section{СПИСОК ЛИТЕРАТУРЫ}

Античная Греция. Проблемы развития полиса: в 2 т. / отв. ред. Е. С. Голубцова. - М.: Наука, 1983.

Аристотель. Сочинения: в 4 т. / пер. с древнегреч. - М.: Мысль, 1976-1983.

Баумейстер А. Статьи из «Энциклопедии эпистемологии и философии науки» // Sententiae. - 2009. - № 2 (XXI). - С. 217-447.

Бэкон Ф. Сочинения в двух томах. - 2-е изд. - М.: Мысль, 1977-1978.

Гаджикурбанова П. А. Аристотель и стоики о природе добродетели [Электронный ресурс]. - Режим доступа к тексту: http://ethicscenter.ru/biblio/SK/gadzhikurbanova.html.

Гаджикурбанова П. А. Специфика стоической трактовки добродетели (понятие «надлежащего по обстоятельствам») // Этическая мысль. - Вып. 5. - М.: ИФ РАН, 2004. - [Электронный ресурс]. - Режим доступа к тексту: http://ethics.iph.ras.ru/em/em5/10.html.

Гайденко П. П. Понимание бытия в античной и средневековой философии // Античность как тип культуры: сб. статей / отв. ред. А. Ф. Лосев. - М.: Наука, 1988. - С. 284-307.

Гомілко О. Беконівське очищення досвіду в модерній програмі десоматизації буття // Sententiae. - 2004. - № 2 (XI). - C. 62-72.

Гьосле В. Практична філософія в сучасному світі. - К.: Лібра, 2003. -248 с.

Диоген Лаэртский. О жизни, учениях и изречениях знаменитых философов / пер. с древнегреч. М. Л. Гаспарова. - М.: Мысль, 1979. - 620 с. 
Ерофеева К. Л. Идеал Просвещения и современность: разочарования и перспективы // Соловьевские исследования. - 2010. - Вып. 2 (26). - С. 90-96.

История древнего мира. Ранняя древность / отв. ред. И. М. Дьяконов. - М.: Наука, 1982. 390 с. с карт.

История древнего мира. Расцвет древних обществ / отв. ред. И. С. Свенцицкая. - М.: Наука, 1982a. -576 с. с карт.

Кузнецов В. Г. Маркиз де Сад: онтология садизма. Статья первая. Сад первобытный // Sententiae. - 2003-2004. - № 1-2, 1 (VIII-X). - C. 77-95.

Кузнеиов В. Г. Маркиз де Сад: онтология садизма. Статья вторая. Сад гностический // Sententiae. - 2004. - № 2 (XI). - C. 44-61.

Кузнецов В. Г. Под игом женщины: просвещенческая диалектика власти Природы и власти над Природой // Sententiae. - 2005. - № 1 (XII). - C. 104-123.

Кузнецов В. Г. Просвещение у пределов: метаморфозы мужественности и женственности // Sententiae. - 2005a. - № 2 (XIII). - C. 168-187.

Кузнецов В. Г. Френсис Бэкон и формирование классической просвещенческой парадигмы Нового времени // Sententiae. - 2006. - № 1-2 (XIV-XV). - C. 89-113.

Кураев А. Традиция, Догмат, Обряд. Апологетический очерк. - М.: Изд-во Братства Святителя Тихона, 1995. $-416 \mathrm{c}$.

Лейбин В. М. Фрейд, психоанализ и современная западная философия. - М.: Политиздат, 1990. -397 с.: фот.

Маркс К., Энгельс Ф. Сочинения - 2-е изд.

Некрасова Н. А., Некрасов С. И., Садикова О. Г. Тематический философский словарь: Учебное пособие. - М.: МГУ ПС (МИИТ), 2008. - [Электронный ресурс]. - Режим доступа к тексту: http://www.terme.ru/dictionary/907/word/prosveschenie

Нерушева Л. Г. «Я ем пепел, как хлеб...» Карл Маркс - ветхозаветный пророк // Союз писателей. - Б. г. - № 5. - С. 192-206.

Панич O. Філософія вчинку Бахтіна в контексті антиметафізичних проектів пізньомодерної європейської філософії // Sententiae. - 2012 - № 2 (XXVII). - С. 5-17.

Платон. Собрание сочинений: в 4 т. / пер. с древнегреч. - М.: Мысль, 1990-1994.

Прокопенко В. Діалог «Феаг» і його місце в освітній філософії Платона // Філософська думка. - 2012. - № 1. - С. 59-76.

Просвещение // Философский энциклопедический словарь / Ред.-сост. Е. Ф. Губский и др. М.: ИНФРА-М, 2005. - [Электронный ресурс]. - Режим доступа к тексту: http://xn-80aa5baeer3bzc.xn--p1ai/lagry/philosophy/filosofskij_ehnciklopedicheskij_slovar'_red_sost_e_f_gubskij_g_v_korableva_v_a_lutchenko_m_ infra$\mathrm{m}$ 2005_576_s_18.html.

Реале Д. Вступ до прочитання «Бенкету» Платона // Платон. Бенкет / перекл. 3 давньогрецької і коментарі Уляна Головач. - Львів: Видавництво Українського Католицького Університету, 2005. - C. IX-XLIV.

Сенека Луц̧ий Анней. Нравственные письма к Луцилию / пер. с лат. - М.: Наука, 1977. $383 \mathrm{c}$.

Титаренко И.Н. Философия Луция Аннея Сенеки и ее связь с учением Ранней Стои. Ростов н/Д: Изд-во СКНЦ ВШ, 2002. - 272 с.

Философия эпохи ранних буржуазных революиий / ред. Ойзерман Т. И. и др. - М.: Наука, 1983. $-583 \mathrm{c}$.

Фролов Э. Д. Огни Диоскуров. Античные теории переустройства общества и государства. Л.: Изд-во ЛГУ, 1984. - 192 с.

Хайдеггер М. Время и бытие: Статьи и выступления / пер. с нем. В. В. Бибихина. - М.: Республика, 1993. - 447 с.

Чанышев А. Н. Курс лекций по древней философии. - М.: Высш. шк., 1981. - 374 с.

Шкуринов П. С. Философия России XVIII века: Учеб. пособие для вузов. - М.: Высш. шк., 1992. $-256 \mathrm{c}$. 
Шоню П. Цивилизация классической Европы / пер. с фр. В. Бабинцева. - Екатеринбург: УФактория, 2005. - 608 c.

Marx K. Ökonomisch-philosophische Manuskripte aus dem Jahre 1844 // K. Marx u. F. Engels. Werke. - Ergänzungsband, 1. Teil. - Berlin (DDR): Dietz Verlag, 1968. - S. 465-588.

Seneca. Ad Lucilium epistulae morales in three volumes with an English translation by R. M. Gummere. - V. I. - Cambridge, Massachusetts: Harvard University Press; London: William Heinemann LTD, MCMLXXIX. - XV, $467 \mathrm{p}$.

Seneca. Ad Lucilium epistulae morales in three volumes with an English translation by R. M. Gummere. - V. II. - London: William Heinemann; New York: G. P. Putnam's Sons, $M C M X X$. - VI, $480 \mathrm{p}$.

Seneca. Ad Lucilium epistulae morales in three volumes with an English translation by R. M. Gummere. - V. III. - London: William Heinemann; New York: G. P. Putnam's Sons, $M C M X X V$. - VI, 463.

The Works of Francis Bacon, baron of Verulam, viscount St. Albans, and Lord High Chancellor of England, 15 vol. / collected and edited by J. Spedding, R. L. Ellis and D. D. Heath. - Boston: Houghton, Mifflin and Company; Cambridge: The Riverside Press, 1990.

Стаття одержана редакцією 17.09.2012

\section{Vsevolod Kuznetsov}

\section{Enlightenment and Ontology. Autochthonous Enlightenments: Europe}

The given article opens a cycle of articles devoted to the ontological aspects of the phenomenon of Enlightenment. The Enlightenment is treated as an internal mechanism of civilization designed to manipulate being (establishment in being - deprivation or attenuation of being). Comparing autochthonous and borrowed Enlightenments, the author tries to trace some patterns of interactions of ontologizing mechanisms of the enlightenmental type and to compare them with the similar mechanisms of different types. In the first article the author analyses the ideas of autochthonous European Enlightenment from Antiquity to Post-Modern.

Vsevolod Kuznetsov, Senior lecturer at the Department of Philosophy in Vinnytsia National Technical University.

Всеволод Кузнецов, старший викладач кафедри філософії Вінницького начіонального технічного університету.

Всеволод Кузнецов, старший преподаватель кафедры философии Винницкого национального технического университета. 